\title{
MUSIIKKI KULTTUURIHISTORIASSA: NORMI- JA ARVOTUTKIMUKSEN NÄKÖALOJA
}

\section{Peruskysymysten äärellä}

Mitä tekemistä kulttuurihistorialla voisi olla musiikin - tai pikemminkin erilaisten musiikkien - kanssa? Eikö musiikin ja musiikkikulttuurien historian tutkimus tulisi jättää varsinaisille musiikkitieteilijöille tai etnomusikologeille, koska aihepiiri tuntuu vaativan erityislaatuisia tietoja ja valmiuksia? Epäilyksiä on riittänyt, kun tämän kaltainen perinteiset oppiainejaot ylittävä ongelma on noussut keskustelun kohteeksi.

Asenteet ovat ymmärrettäviä. Musiikin historiaa sanan vaativassa mielessä ei ole tähän mennessä juuri muualla harrastettu kuin musiikkitieteilijöinä itseään pitävien keskuudessa. Ammattihistorioitsijoiden aktiivinen poissaolo musiikin tutkimuksen alueilta on taannut sen, että musiikkitiede on ainakin Suomessa saanut yksin määritellä pätevän musiikinhistorian sisällön ja rajat. Lopulta institutionaalisten reviirien ylläpito on kääntynyt kysymykseksi opiskelijoiden ja tutkijoiden identiteetistä. Koulutus- ja oppialataustansa ulkopuolelle etsiytyvä ja henkisiin raja-aitoihin päätään kolhiva voi helposti unohtua tieteenharjoituksen marginaalialueelle.

Kulttuurihistorian parissa askarteleva joutuu kohtaamaan myös muita ongelmia. Kulttuurihistoria on merkinnyt monissa yhteyksissä rattoisia ta- 
rinoita värikkäästä menneisyydestä, ts. miellyttävää viihdytystä vailla tieteellistä kunnianhimoa. Maallikkolukijan mielessä sana yhdistyy edelleenkin "jokapäiväiseen elämään antiikin Roomassa" tai vaikkapa "renessanssitaiteen aarteisiin". Niin ikään korkeakulttuuriset tai elitistiset painotukset ovat olleet etualalla. Näin ei tarvitse olla eikä näin pidäkään olla. Nykyhetken yleinen kulttuurintutkimus sekä yhteiskuntatieteet asettavat jatkuvasti uusia haasteita historioitsijoille systematisoida omia lähtökohtiaan. En tarkoita nyt mitään abstraktia malliajattelua. Esimerkiksi sosiologit näyttävät tänä päivänä tuntevan oman perinteensä lisäksi myös historiantutkimusta. Tutkijan on kysyttävä itseltään aivan yksinkertaisesti, mikä hänen kohteensa todella on ja mikä on hänen näkökulmansa. Tämä artikkeli on syntynyt juuri noista tarpeista.

Kulttuurihistoriassa on musiikin suhteen mahdollista harrastaa intellektuaalista ympärilleen katselemista. Opinalalla ei ole taakkanaan vakiintunutta musiikin tutkimuksen perinnettä eikä siihen soveltuvaa "oikeaoppista" metodologiaa. Lisäksi olisi epätarkoituksenmukaista ryhtyä tekemään juuri musiikinhistoriasta yhtä sen painoaloista. Kulttuurihistoriaa eivät sido akateemisen musiikintutkimuksen ahtaat tyyli- ja teosanalyyttiset perinteet eivätkä esimerkiksi sellaiset esteettiset normistot, jotka ovat saaneet suomalaisen musiikkitieteen suuntautumaan lähes yksinomaan nk. länsimaisen taidemusiikin tutkimukseen. Institutionaalisen ja metodologisen väljyyden ei pidä tietystikään houkutella välinpitämättömyyteen musiikkitiedettä ja vakiintunutta akateemista musiikintutkimusta kohtaan. Ylimielisyyden takia jää helposti yksin. Musiikinhistoriasta kiinnostuneen kulttuurihistorioitsijan on kyettävä seuraamaan ja myös käyttämään hyväksi musiikkitieteilijöiden tutkimuksia ja heidän käymiään keskusteluja. Kukaan ei voi lähteä nollatilanteesta.

Koetan seuraavassa tehdä selkoa musiikin historian tarkasteluperiaatteista nk. normi- ja arvotutkimuksen näkökulmasta. Olisi liioiteltua puhua itsenäisestä tutkimussuuntauksesta, joka loisi riittävän teoreettisen ja metodologisen perustan kulttuurihistoriallisen musiikin tutkimisen kaikkiin tarpeisiin. Tutkimuksen kenttä on sen verran laaja ja monimuotoinen, ettei sitä voi missään nimessä hallita yhden näkökulman kautta. Normi- ja arvotutkimus on toki vain yksi mahdollisuus monien muiden kilpailevien näkökulmien joukosta. Itse asiassa sen avaamia aspekteja on löydettävissä useista erillistutkimuksistakin pirstaleisessa muodossa.

Normi- ja arvotutkimuksella on kuitenkin yksi merkittävä ominaisuus moniin muihin tarkasteluperspektiiveihin verrattuna. Se ei asianmukaisesti toteutettuna eristä kohdettaan menneisyyden ihmisten subjektiivisuudesta omalakiseksi ilmiöksi. Normi- ja arvotutkimus pyrkii vakavasti pohti- 
maan, miten nämä ihmiset ymmärsivät musiikiksi kutsumansa ilmiön ja miten he sitä määrittelivät sekä intellektuaalisella että toiminnallisella tasolla. Se, mitä ja miten musiikki merkitsi entisajan sukupolville, ei ole normi- ja arvotutkimuksen lähtökohta, vaan sen lopputulos. Menneisyyden ihmisten puolustamia periaatteita ei objektivoida naiiviin tapaan heti alussa, vaan etsitään ja valaistaan eri puolilta koko tutkimusprosessin ajan. Menettelytavan kautta tematisoituu silloin erinäisiä keskeisiä kysymyksiä, jotka liittyvät välittömästi oman aikamme ja kulttuuripiirimme pätevinä pidettyihin uskomuksiin musiikista. Menneisyyden normeihin ja arvoihin perehtyminen saa meidät pohtimaan ennakkokäsityksiämme musiikista ja kenties pääsemään selville myös oman yhteiskuntamme musiikkia koskevien normien historiallisesta ehdollistuneisuudesta.

Musiikillinen normi- ja arvotutkimus liittyy ajattelu- ja suhtautumistapojen historiaan, musiikkikulttuureja rakentaviin ja ylläpitäviin sosiaalisiin sidoksiin. Sen avulla voi valaista tiettyjen yhteisöjen, instituutioiden tai osakulttuurien sisäistä yhtenäisyyttä luovia edellytyksiä musiikkia koskevissa kysymyksissä. Kulttuurihistoriassa esitetty vaatimus tarkastella musiikkia aina osana aikansa yhteiskuntaa ja sen muita toimintoja täsmentyy täten konkreettiseksi tutkimusvaihtoehdoksi.

Tässä kohden on paikallaan tähdentää, ettei 'kulttuuri' ole jokin erillinen elämänalue muiden alueiden rinnalla ('yhteiskunta', 'politiikka' jne.), vaan se muoto, jolla kaikki nämä toiminnot jäsentyvät kokonaisuudeksi. Tämä muoto ilmenee subjektille välttämättömyyden tunteena siitä, että ilmiöt ja asiat liittyvät toisiinsa. Normeiksi voimme silloin tulkita niitä erityisiä, historiallisesti ja sosiaalisesti vaihtelevia periaatteita, joiden nojalla tämä jäsentyminen tapahtuu. Musiikki ei siksi kytkeydy yhteisöelämään joidenkin yksiselitteisten empiiristen seikkojen, vaan yksinomaan ajatteluja toimintatapojen perusteella. Kulttuurihistorioitsijan tutkimuskohteita ovat juuri nämä tavat ja niiden taakse kätkeytyneet periaatteet.

\section{Kohti musiikin yhteisöllisten määritysten ja merkitys- ten tutkimusta}

Länsimaiseen taidemusiikkiin 1800-luvulla kiinteästi pesiytynyt autonomiaperiaate sekä teoksen kategoria, joka korosti sävellyksen itsenäistä ja itsessään tarkoituksenmukaista luonnetta, loivat tieteenharjoitukseen edellytykset ja perusteet ryhtyä yksityiskohtaisesti analysoimaan musiikillisen materiaalin sisäsyntyisiksi tulkittuja ominaisuuksia. Tällöin tutkimus paljasti teoksista ja niiden esityksistä monia ennen huomaamattomia 
sisäisesti funktionaalisia yhteyksiä. Tutkija saattoi tarkastella musiikillisen materiaalin jaksotusperiaatteita ja laajempia muotoja, harmonista "logiikkaa" tai kognitiivisia prosesseja, jotka saattoivat ilmetä vain musiikillisesti. Näkökulma painottui teoksiin itseensä. Tutkijan oli tunnettava vain riittävästi musiikin teoriaa, analyysivälineet ja tyylien sekä lajiperinteiden historiallisia kriteerejä. Näin hänelle kävi mahdolliseksi saavuttaa pätevää uutta tietoa valitsemastaan kohteesta.

Tällainen tyyli- ja teosanalyyttinen lähestymistapa oli pitkään musiikkitieteelle ominainen ja on sitä vieläkin. Tasapuolisuuden nimissä on kuitenkin todettava, että sekä saksalaisella että anglosaksisella kielialueella modernin musikologian kenttä on viime vuosikymmeninä paljon avartunut. Pyrkimykset kohti musiikin reseptiohistoriaa, musiikki-instituutioiden sosiaalihistoriaa, esteettisten normistojen ja arvojärjestelmien historiaa tai musiikillisten paikallisyhteisöjen ja osakulttuurien monipuolista tarkastelua ovat muuttaneet musiikkitieteenkin kokonaiskuvaa.

Viimeksi mainittujen aihepiirien tulo musiikintutkimukseen on ennen kaikkea etnomusikologian ansiota. Se sekä populaarimusiikin tutkimus ovat kokeneet Suomessa lupaavalta vaikuttavan nousukauden muun kulttuurintutkimuksen vilkastumisen myötä 1980-luvulla.

Tavoitteeksi on otettu musiikin tarkastelu sen yhteisöllisten merkitysten ja käytäntöjen, sen yhteiskunnallisen välittyneisyyden ja inhimillistä kokemusmaailmaa jäsentävien ulottuvuuksien kautta. Nämä ovat juuri niitä perspektiivejä, joita kulttuurihistoria voi omaksua ja joita sen on syytä yrittää kehittää eteenpäin. On vähitellen huomattu, että kyllästymiseen asti toisteltu väite musiikin abstraktisuudesta ei palaudukaan "ilmiöön sinänsä", musiikin aineettomaan tai ei-sanalliseen olemukseen, vaan on autonomiaperiaatteen luoma normi. (Tässä kohden voi myös soveltaa hegeliläistä kritiikkiä. Kun musiikista on ihmisten tietoisuudessa tullut abstraktia yhä lisääntyvän työnjaon seurauksena, se on jo menettänyt kykynsä tunnistaa alkuperäänsä ja siten muuttunut tyhjäksi spekulaatioksi vailla yhteyttä ihmisten elämänkäytäntöihin. Väite musiikin abstraktisuudesta on siis jo itsessään ilmaus tietystä yhteiskunnallisesti välittyneestä suhteesta musiikkiin ja niin muodoin mielenkiintoinen tutkimuskohde kulttuurihistoriassa.)

Musiikillisen autonomian perustalle kehitettyyn metodologiaan sisältyvät julkilausumattomat ennakkokäsitykset musiikin luonteesta osoittavat, ettei mikään tieteellinen menetelmä ole loppuun saakka vapaa musiikin merkityksissä ja yhteiskunnallisessa asemassa tapahtuvista muutoksista. Esteettisten normistojen tarkastelu suo kulttuurihistorian tutkijalle myös mahdollisuuden luoda kriittistä etäisyyttä vakiintuneen musiikintutkimuksen perinteisiin lähestymistapoihin ja metodeihin. 
Hakeutumisessa uusien tutkimuskohteiden ja näkökulmien ääreen emme voi kuitenkaan tehdä muuta kuin lähteä ensi alkuun liikkeelle omasta esiymmärryksestämme. Eurooppalais-angloamerikkalaisen kulttuuripiirin jäsen kohtaa tällä tiellä edelleen varmasti yllätyksiä. Länsimaisen ihmisen tietoisuus musiikista on näet pitkälti tuotettu sen käsityksen varassa, että niin kuin etnomusikologi John Blacking aikoinaan totesi - musikaalisuus olisi jotenkin erillinen lahjakkuuden muoto tai kyky. Tätä käsitystä ylläpitämällä osa musiikillisista traditioista on jätetty yleisesti hyväksytyn tutkimuksen ulkopuolelle. Systemaattinen musiikinopetus ja -koulutus oppilaitoksissa, kohdistaessaan huomionsa erityiseen "musikaalisuuteen", on puolestaan säädellyt käsityksiä siitä, mitä ilmiöitä ja asioita on lupa lukea musiikin käsitteen piiriin ja mitä ei.

Kuten musiikin määrittelyyn ja sen akateemiseen tyyli- ja teosanalyyttiseen käsittelytapaan liittyvistä aspekteista voi panna merkille, musiikin sosiaalisesti ehdollistunut tunnistaminen ja hyväksyttäväksi tekeminen tapahtuu milteipä huomaamattomasti, kasvamalla ja kehittymällä määrättyihin konventioihin. Musiikillista käyttäytymistä ja merkityksenantoa ohjailevat esitietoiset tavat ja normit. Esitietoinen tajunnanulottuvuus ei tässä yhteydessä liity lainkaan epähistoriallisesti suuntautuneisiin psykologisiin tai psykoanalyyttisiin teorioihin ihmismielen mekanismeista. Kyse on intersubjektiivisesti määräytyneistä, kollektiivisista ajattelutottumuksista ja asenteista, jotka tavallaan "lyövät kiinni" subjektin kokemus- ja tietomaailman rajat hänen osallistuessaan yhteiskunnallisiin käytäntöihin. Normit eivät kuulu maailmaan, mutta ilmenevät siinä. Ne eivät ole osa musiikillista empiiristä todellisuutta, vaan itse asiassa tuottavat sellaisen. Tutkijalle tämä merkitsee, että normit eivät ole havainnollisen yksiselitteisesti annettuja, vaan ne on aina rekonstruoitava.

Musiikilliset normit liittyvät lähinnä määrittely-, tunnistamis- ja oikeuttamiskysymyksiin. Musiikkia koskevat arvot puolestaan ilmaisevat niitä merkityksiä, joita subjekti antaa tietyille empiirisille musiikillisille ilmiöille tai toiminnan päämäärille normien puitteissa. Jyrkkä rajanveto normien ja arvojen välillä ei ole historiantutkimuksessa kuitenkaan tarkoituksenmukaista. Missä tutkitaan musiikillisia arvoja, siellä joudutaan aina rekonstruoimaan myös normeja. Missä taas lähdetään tarkasti liikkeelle musiikkiesteettisistä normeista, siellä otetaan yleensä konkreettisia esimerkkejä arvojen alueelta.

Laajalle levinnyt ja sosiaalisesti vakiintunut musiikkia koskeva normi omassa kulttuuripiirissämme on erilaisten musiikkien tai musiikin lajien määrittely länsimaisen taidemusiikin saaman institutionaalisen aseman kautta. Varsinkin etnomusikologit ovat tähdentäneet tätä seikkaa. Aikam- 
me yhteiskunnassa, esim. koulutuksessa ja joukkotiedotuksessa, 'musiikki' ilman sen kummempia lisämääreitä merkitsee yleensä taidemusiikkia, vieläpä vain klassisromanttisen kauden orkesterikirjallisuutta. Se katsotaan musiikkikulttuurimme arvokkaimmaksi osaksi. Sen sijaan muut musiikin muodot ja lajit ovat alalajeja kyseisestä yleisestä kategoriasta. Tapaamme populaarimusiikkia, kansanmusiikkia, rockmusiikkia, tanssimusiikkia jne. Tässä tapauksessa musiikillisten ilmiöiden empiirinen luokittelu tuo välittömästi tullessaan sellaisen erojen tekemisen ja hierarkian rakentamisen mekanismin, jossa taidemusiikiksi kutsuttu traditio (ja sen teosten kaanon) edellytetään luokittelun perustaksi a priori. Normille löytyy historiallinen taustansa konsertti-instituution ja romantiikan ajan idealistisen hengenfilosofian kehityksestä modernin ajan Euroopassa. Aihepiiriä ei ole tutkimuksissa varmastikaan vielä ammennettu tyhjiin.

Theodor W. Adornon lukuvuonna 1961-1962 Frankfurtissa pitämien musiikkisosiologisten luentojen merkittävimpiä ajatuksia on, että ihmisten musiikillinen tietoisuus on aina yhteiskunnallisesti tuotettua. Adorno kiisti kuvitelman "onnellisen musiikillisen luonnontilan" olemassaolosta sosiaalisten järjestelmien tuolla puolen. Ihmiset havaitsevat ja toimivat musiikissa juuri niin kuten he ovat siihen ehdollistuneet ihmisyhteisössä kasvaessaan. Tässä mielessä musiikkia koskevat normit ovat aina olleet tuottavia sosiaalisia voimia, eivät rajoittavia. Normeja vastaan on tietysti kapinoitu, mutta se ei ole ollut ilmaus ehdotonta vapautta janoavista subjekteista, vaan toisista normi- ja arvomaailmoista. Nämä ovat tavoitelleet itselleen yhtä suurta oikeutta hyväksyttävään olemassaoloon muiden musiikillisten osakulttuurien rinnalla.

Kullakin musiikillisella osakulttuurilla on omat esteettiset normistonsa ja arvonsa. Tämä historiallinen tosiasia on johtanut esimerkiksi siihen, että taide- ja populaarimusiikin tutkimusalueet ja -perinteet ovat pysytelleet hyvin pitkälle erossa toisistaan. Paljon keskusteluja on aiheuttanut kysymys siitä, voidaanko näitä eroja perustella kriteereillä, jotka olisivat löydettävissä musiikillisesta materiaalista itsestään. Adorno teki selviä laadullisia hierarkioita musiikillisten ilmiöiden välille sen mukaan, mikä oli niiden 'totuudellisuusaste'. Kriteerinä oli, miten hyvin ne kykenivät ilmaisemaan kulloisenkin yhteiskunnallisen tilanteen (hegeliläisittäin: 'hengen') kehitysasteen. Musiikillinen materiaali oli säveljärjestelmineen kaikkineen Adornon mukaan läpikotaisin historiallista. Hänelle klassisromanttiseen tonaalisuuteen ankkuroituneet aikamme musiikin muodot olivat taantumia, yhteiskunnallisesti koteloituneita tietoisuuden asteita. Esimerkiksi populaarimusiikin harrastuksessa "massat nauttivat omasta alennustilastaan".

Tällaista kantaa musiikkia koskevien normistojen ja arvojen tutkijan 
on vaikea hyväksyä. Hänelle erilaiset osakulttuurit ovat keskenään relatiivisia ja joskus täydelleen yhteismitattomia. Jokainen vähänkin oudolta tuntuva käsitys musiikista asettaa haasteen tutkijan ymmärryskyvylle. Normija arvotutkimuksen myötä länsimaisen autonomiaperiaatteen vaalima ajatus universaalin hengen kehityskulusta on osoittautunut historiallisesti suhteelliseksi, eurooppalaisen sivistysporvariston puolustamaksi yhteiskunnalliseksi projektiksi. Tilalle ovat nousseet intellektuaalinen pluralismi ja traditioiden moninaisuuden tunnustaminen.

\section{Modernin musiikinhistorian rationalisointiyritys: porvarillisen konserttikulttuurin ideaalityyppi}

Musiikin normi- ja arvotutkimus ei loppujen lopuksi kerro vielä mitään siitä, ovatko musiikin historiankirjoituksen perimmäiset liikevoimat esim. talous- ja sosiaalihistoriallisia vai musiikin kehityksen "suhteelliseen autonomiaan" nojaavia. Se haluaa itse asiassa tehdä tyhjäksi koko kysymyksen. Normit ja arvot ovat jo sinänsä tärkeitä intersubjektiivisia tekijöitä, joiden uusintaminen ja ylläpito sisältää samanaikaisesti taloudellisia, intellektuaalisia, tai yhteiskunnallisia ulottuvuuksia. Näille taas on esitietoisten ajattelutottumusten tarkastelussa mahdotonta rakentaa kertakaikkista hierarkiaa. (Klisheeksi muuttunut lausahdus "kaikki riippuu kaikesta" ei ehkä sittenkään ole niin sisällöllisesti tyhjä kuin yleensä ajatellaan.)

Monimutkaisten vuorovaikutussuhteiden esimerkinomaiseksi valaisemiseksi on tässä kohden soveliasta esitellä pääpiirteissään yksi modernin ajan musiikinhistorian vaikutusvaltaisimmista esteettisistä normistoista $\mathrm{Eu}-$ roopassa. Sen aiemman institutionaalisen ja koulutuksellisen hegemonian takia siihen törmäävät hyvinkin aikaisessa vaiheessa paitsi tietysti taidemusiikin, niin myös populaari- ja kansanmusiikin historian tutkijat länsimaissa. Kirjassaan Grundlagen der Musikgeschichte (1977) Carl Dahlhaus sommittelee eräänlaisen kategorioiden ja ideoiden verkoston, jonka voi kriittisellä mielellä omaksua lähtökohdaksi 1800-luvun keskieurooppalaisen porvarillisen musiikkikulttuurin tutkimukselle oopperaa lukuun ottamatta. Se ei ole sellaisenaan ilmennyt empiirisesti missään. Malli on tulkittavissa ideaalityypiksi, yritykseksi laatia Max Weberin hengessä rationaalinen ja systemaattinen perusta myöhemmille yksityiskohtaisille tarkasteluille. Se näyttää suuntaa tutkimusohjelmien laatimiselle. Dahlhausin esityksen kriittinen kärki on suunnattu puhdaslinjaista marxilaisuutta vastaan ja lähtee liikkeelle musiikillisen autonomian periaatteesta. Sitä ei pidä silti lukea kannanotoksi idealistisen "hengenhistorian" puolesta. 
Tällainen menettelytapa ei ole tietenkään konkreettista empiiristä tutkimusta eikä sillä ole sellaiseen pyrittykään. Kyse on määrättyjen esteettisten käsitteiden, kategorioiden ja normien julkilausumattomien sisältöjen ja merkitysten etsimisestä. Jonkinlainen vastaava käsitteiden joukko rakentuu jokaisen porvarillista musiikkikulttuuria tutkivan tietoisuudessa. Selvää on, ettei empiirisiä ilmiöitä mekaanisesti yhteen kasaamalla vielä muodostu mitään käsittelyä yhtenäistäviä kategorioita. Sosiaalihistorian vankkumattomien kannattajien on hyvä muistaa, että myös menneisyyden materiaalista ja sosiaalista todellisuutta tutkitaan käsitteellisin ehdoin. Aivan toinen kysymys sitten on, onko meidän lopultakaan pidettävä kiinni tästä Dahlhausin esittämästä mallista. Suuri palvelus musiikin normi- ja arvotutkimukselle olisi, jos mallin tilalle kyettäisiin nostamaan toisenlaisista yhteyksistä käsitteensä hakeva tulkinta.

Autonomiaperiaate lähti porvarillisen konserttikulttuurin alkuaikoina 1700-luvun loppupuolella siitä, että musiikkia voitiin kuunnella sen itsensä takia vailla ulkomusiikillisiksi katsottuja tehtäviä (esim. ruhtinaan vallan representaatio hovimusiikissa tai Jumalan kunnian esitys kirkkomusiikissa). Autonomiavaatimuksen sisäinen yhteys genius-estetiikkaan ja originaalisuuden ideaan yhtäältä sekä musiikkiteosten tavaraluonteeseen toisaalta on ilmeinen. Kuitenkin näiden tekijöiden sopivan keskinäisen painotuksen löytäminen on hankalaa. Talous on yleisenä perustana varsin merkittävä 1800-luvun musiikinhistoř̃assa, mutta autonomiaperiaatteen historiallisia yksityiskohtia tarkasteltaessa on jo oltava varovaisempi. Missä määrin musiikin tavaraluonne oli todella sisäänrakennettuna teoksen ideaan? Mitkään yksinkertaiset taloudellis-sosiaaliset selitykset, esim. vaatimukset 'alarakenteen' ensisijaisuudesta, eivät tule kyseeseen. Ensiksikin säveltäminen muodosti 1800-luvulla pienen osan säveltäjien taloudellisesta toimeentulosta. Toiseksi musiikin tavaraluonteeseen sisältyväksi ajateltu pakko menestyksen hyödyntämiseen vaikka sitten omia teoksiaan jäljittelemällä toteutui konserttimusiikissa vain osittain. Se oli näet selvässä ristiriidassa originaalisuuden idean kanssa, joka edellytti säveltäjältä jokaisessa teoksessa aina "välittömyyttä" ja uutuutta. Esteettinen normi oli taloudellista laskelmointia voimakkaampi.

Autonomiaperiaatteen institutionaalinen ilmentymä oli porvarillinen konserttilaitos, joka vakiintui nopeasti poliittisen restauraation aikakautena vuoden 1815 jälkeisessä Euroopassa. Vuosisadan puoliväliin mennessä se oli kehittynyt Dahlhausin mukaan lähimmäksi tässä kuvattua ideaalityyppiä. Nk. taidemusiikin vaatimuksena oli tulla kuulluksi sen itsensä takia "hengen työnä hengelle alttiissa materiaalissa" (Eduard Hanslick). Sille asettui kuuntelua ja konserttikäyttäytymistä koskevaksi normiksi esteetti- 
nen mietiskely, jota Arthur Schopenhauer oli perusteellisesti kuvaillut. Väite, että autonomiaperiaate kehittyi kohti varsinaista sinfoniakonserttikäytäntöä vuosisadan puoliväliin mennessä ankaran taidevaatimuksen merkeissä, ei kuitenkaan merkitse silmien ummistamista konsertti-instituution muilta tehtäviltä. Esteettinen normi muokkasi ohjelmistoja ja loi konserttikulttuuriin yleisen ihanteen oikeasta taidekokemuksesta. Sen rinnalla säilyivät kuitenkin konsertin seurallis-viihteelliset ja edustukselliset tehtävät sekä esim. soittimellisen virtuoosisuuden palvonta.

Autonomiaperiaatteen sävellystekniseksi vastineeksi Dahlhaus jäsentää eräänlaisen kompleksin, jonka tunnusmerkkeihin kuuluvat

1) instrumentaalimusiikin itsenäisyys (soitinmusiikin vapautuminen "ulkomusiikillisista" päämääristä sekä pelkistä alku- ja välisoittotehtävistä)

2) tonaalisen harmonian muotoja luova merkitys (keksintö, että tonaalisuuden avulla kyetään rakentamaan ja hallitsemaan laajoja muotoja puhtaan musiikillisesti, ts. ilman tekstin tai ohjelman koossapitävää merkitystä)

3) temaattis-motiivisen työskentelyn menetelmä.

Näin autonominen soitinmusiikki oli ymmärrettävissä soivaksi esitykseksi "logiikasta", joka oli sisäänrakennettu tonaalisiin muotoihin ja temaattis-motiivisiin yhteyksiin. Uudet sävellystekniikat lunastivat autonomiaperiaatteen asettaman vaatimuksen. Kuuntelun ulkoisten puitteiden vaihtumisen ohella myös musiikillinen materiaali muuttui. Vielä vuoden 1800 tienoilla autonominen soitinmusiikki - vailla kirjallista ohjelmaa, vailla virtuooseja, vailla houkuttelevuutta tanssiin - oli ollut pikemminkin paradoksi kuin yleisesti hyväksytty käytäntö.

Siten kuin 1800-luvun porvaristo ymmärsi musiikillisen autonomian normin, sillä ei ollut Saksassa mitään tekemistä l'art-pour-l'art -periaatteen kanssa. Soitinmusiikin kuuntelu konserteissa ei merkinnyt musiikin eristäytymistä, vaan osallistumista humboldtilaiseen sivistyksen ideaan, joka kuului aikakauden tärkeisiin keskustelun ja pohdinnan aiheisiin. Autonominen musiikki oli aristokraattisen vapauden aluetta. Kuuntelu loi välimatkan arkipäivän pakkoihin ja hyödyntavoitteluun. Musiikki oli vapautusta taloudellis-sosiaalisesta elämänkäytännöstä, jossa kaikki ihmiset olivat toisilleen vain välineitä.

Autonominen musiikki sai keskeisen filosofisen oikeutuksensa ajatuksesta, että se on geniuksen, neron työtä. Konserttimusiikin kuuntelijalle sälytetty kaksinkertainen vaatimus yhtäältä "soivan logiikan" tiiviistä seuraamisesta sekä toisaalta säveltäjän yksilöllisyyden ja originaalisuuden käsittämisestä tunteen avulla sisältyi musiikin "ymmärtämisen" normiin. Siinä 
yhtyivät ajatukset rationaalisesta suorituksesta ja yleisinhimillisestä myötätunnosta. Se, että radikaali originaalisuus muodosti geniuksen olemuksen, edusti ilmaisuestetiikan yhtä muotoa. Säveltäjä ilmaisi itseään teoksissaan. Hänen tuli olla aito ja spontaani. Esteettinen minä saatettiin myös samaistaa empiiris-arkipäiväisen säveltäjäminän kanssa, mutta se ei ollut nero-estetiikan varsinainen tarkoitus. Toisaalta originaalisuuden vaatimus edellytti uutuutta. Jäljittelystä tuli hyljeksittävä tapa. Dahlhaus väittää, että uutuuden esteettisessä normissa voi ilman "historianfilosofista väkivaltaa" tunnistaa teollistumisen aikakauden varhaisvaiheissa esiinnousseen edistyksen ajatuksen.

Tämä idea taas suhteutui geniusten kunnioitukseen. Nerojen työt olivat historian yläpuolella - ja siten klassisia. 'Klassisen teoksen' käsitteen käyttöönotosta musiikissa 1700- ja 1800-luvun vaihteessa kehkeytyi vuorovaikutuksessa teosten kasvavien tulkintaongelmien kanssa konserttiohjelmistojen standardi, jonka selkärankana olivat Beethovenin sinfoniat. Ensi näkemältä tuntuisi siltä, että ohjelmistojen vakiintuminen olisi vaikuttanut yksinomaan edistyksen normin vastaisesti. Asia voidaan kuitenkin tulkita myös toisinpäin. 1800-luvulla edellytetystä laadullisesta uutuudesta on erotettava nimittäin kronologisen uutuuden käsite, joka oli ollut itsestäänselvyys edellisellä vuosisadalla. Niin kauan kuin musiikkiteoksen tuli olla selvästi käsitettävä ensimmäisellä kuuntelukerralla - kuten 1700-luvulla, koska sitä tuskin esitettiin uudelleen - se ei voinut olla radikaalisti uutta, paitsi tietysti säveltäjän menestyksen kustannuksella. Mutta kun ilmaantui mahdollisuus kuulla samaa teosta yhä uudelleen, kävi perustavanlaatuisen uutuuden tavoittelu mielekkääksi.

1800-luvun sivistysporvaristo halusi luottaa siihen mahdollisuuteen, että aluksi vaikeasti ymmärrettävä teos osoittautuisi myöhemmin todistukseksi nerouden voimasta. Sitä ei saanut sulkea ulos konsertti-instituution julkisuudesta. Radikaali edistyksellisyys ja innovatiivisuus kytkeytyi odotukseen tulevasta klassisuudesta Dahlhausin mukaan selvimmin Richard Wagnerin kohdalla. Näin lomittuivat toisiinsa genius-estetiikka, edistysajatus ja klassisuuden idea autonomiaperiaatteelle rakentuneessa musiikkikulttuurissa. Sille, että aikamme konserttisaleissa soitetaan enimmäkseen 150200 vuotta vanhaa musiikkia, löytyy historiallinen taustansa kyseisten normien lujasta toisiinsa kytkeytymisestä 1800 -luvun alussa. Siitä oli myös seurauksena, että musiikin historiaa ryhdyttiin jäsentämään pikemminkin sarjaksi yksittäisiä ja yksilöllisiä teoksia kuin kokoelmaksi musiikin lajityyppejä sekä sävellysteknisiä sääntöjä ja käytäntöjä. Lisäksi suuret säveltäjäyksilöt nousivat kunniaan ja maineeseen. Yhä edelleen yleistajuinen kirjallisuus musiikista pursuilee säveltäjäelämäkertoja. Ne pyrkivät yl- 
läpitämään käsitystä, että konserttimusiikin historia jäsentyy galleriaksi luovia persoonallisuuksia.

\section{Musiikin estetiikasta yhteiskunnallisiin aspekteihin}

Musiikkia koskevan historiallisen normi- ja arvotutkimuksen tärkeimpiä tavoitteita on pyrkiä läpivalaisemaan niitä sosiaalisia mekanismeja ja ideologisia rakenteita, jotka ovat saaneet ihmiset suhtautumaan tietynlaiseen musiikkiin tietyllä tavalla. Suhtautumistavat ilmenevät muun muassa esteettisissä arvostelmissa ja puhekäytännöissä. Kulttuurinen juopa on jakanut esimerkiksi taidemusiikin ja populaarimusiikin alueita erilleen toisistaan. Tätä tapahtuu edelleen postmodernista tyylien sekoituksesta huolimatta. Jo yleisesti hyväksytyillä nimityksillä ("taide"-, "populaari"-, "vakava" tai "kevyt" musiikki) implikoidaan eroja. Normi- ja arvotutkimus ei silti pysähdy kieleen, vaan yrittää etsiä niitä laajempia sosiaalisia voimia, jotka saavat ilmaisunsa esteettisissä puhekäytännöissä. Esimerkiksi "suuren taiteen" kaanonin eriyttämistä moniaineksisesta musiikillisten ilmiöiden joukosta ovat säädelleet eri instituutiot, valtasuhteet ja tiettyjen yhteiskuntaryhmien sosiaalihistoria.

Normi- ja arvotutkimuksen tehtävänä ei ole kuitenkaan osoittaa näitä eroja mielivaltaisiksi tai toissijaisiksi ikään kuin kaikki musiikki olisi pohjimmiltaan samanlaista. Suhtautumis- ja ajattelutavat eivät ole musiikillisen materiaalin tuottamisen ja reseption kannalta mitään ulkoista pintaa, vaan toimivat intersubjektiivisina edellytyksinä musiikillisille kokemuksille. Samalla kun normit säätelevät käsityksiä musiikista, ne myös tuottavat meille ymmärryksen itsestämme musiikkia tekevinä, esittävinä ja kuuntelevina yksilöinä. Se, miten ihmisten ajatellaan toimivan ja elävän musiikissa, kertoo lisäksi siitä, millaiseksi olennoksi normit pyrkivät häntä yleensäkin määrittelemään. Siksi musiikkia koskevista normistoista ja arvojärjestelmistä on luettavissa esiin yhteiskunnallinen aspekti. Se saa ilmaisunsa usein estetiikan tai taidefilosofian kielellä. Tutkijan intressinä ei ole niinkään puolustaa jotakin esteettistä normistoa muiden kustannuksella, kuten monet musiikkitieteilijät ovat tulleet tehneeksi. Sen sijaan hänen tulee luoda tulkinta siitä, mitä tietynlainen musiikki on merkinnyt historiallisessa ajassa ja paikassa. Minkälaisen käsityksen ihmisen kokemusmaailman luonteesta, rajoista ja mahdollisuuksista musiikkiesteettiset normit ovat pyrkineet tuottamaan?

Jos vielä kerran palaamme taide- ja populaarimusiikin osakulttuurien välisiin eroihin, voi tällä alueella nähdä ahtaasti esteettisten kysymysten li- 
säksi myös keskustelunaiheita, jotka ovat pitäneet sisällään laajempia yhteiskunnallisia näkökohtia. Millaisiin sivistysihanteisiin, käytös- ja moraalisääntöihin taidemusiikin puolustama, 1800- luvulla kehittynyt musiikillinen autonomia on perustunut eri aikoina ja eri paikoissa? Miten se on tuotettu esim. konserttikäyttäytymisen tasolla? Millaisia erilaisia tulkintoja sille on annettu? Populaarimusiikin kohdalla voidaan kysyä, mitä merkitsi esim. 1960-luvun rockin sosiaalinen "kapinallisuus". Mitkä olivat ne normit, joita se rikkoi ja joita se itse ei saanut rikkoa? Entä millaisia yhteiskunnallisia ulottuvuuksia kantoi punkin "autenttisuus" tai "rehellisyys" sisässään 1970-luvun loppupuolella? Mitä moraalisesti ja intellektuaalisesti epäilyttävää on sisältynyt koko populaarimusiikin perinteeseen taidemusiikkikulttuurin näkökulmasta? jne.

\section{Lähdemateriaalista}

Edellä todetun nojalla on selvää, että kulttuurihistoria käyttää normi- ja arvotutkimuksessa ensi sijassa kirjallista aineistoa. Audiovisuaalisen materiaalin merkitys kuitenkin korostuu mitä lähemmäs omaa aikaamme tulemme. Se, mitä on yleisessä kielenkäytössä kutsuttu estetiikaksi, on normi- ja arvotutkimuksen ydinaluetta. Niinpä kaikenlainen aihepiirin aikalaiskirjallisuus, sekä teoreettinen että välittömään konkreettiseen käyttöön tarkoitettu, muodostaa yhden ensi käden lähteiden ryhmän: oppi- ja kurssikirjat koulutuskäyttöön, tieteelliset tutkimukset, esteettiset traktaatit ja kirjaset, pamfletit, käsikirjat jne.

Toinen ja luultavasti tärkein aineistoluokka koostuu joukkotiedotuksen tuottamasta lähteistöstä. Tämä tarkoittaa etupäässä sanoma- ja aikakauslehdistöä. Mutta emme saa unohtaa myöskään radio- ja televisio-ohjelmia, videota, elokuvaa tai vaikkapa konserttien esittelylehtisiä. Lehdistön artikkelit, tiedotuspalstat sekä ennen kaikkea konsertti- ja levykritiikit vaikuttavat kuitenkin antoisimmilta lähteiltä, koska niillä on ollut selkein arviointi- ja maunmuodostustehtävä. Monien reseptiomallien, mielipiteiden ja arvostusten syntymistä ja levittäytymistä voidaan tutkia nimenomaan lehdistön avulla. Se on yleensä vakiinnuttanut yhteisöllisiä esteettisiä normeja julkisuudessa.

Lopuksi on paikallaan mainita vielä kolmas, työläämmin käytettävissä oleva lähderyhmä. Tähän sisältyy konserttiohjelmistoja, musiikkioppilatosten tutkinto- ja suoritusvaatimuksia, äänitteiden ja levyjen julkaisuluetteloita, hittilistoja, painettuja nuottikokoelmia, laulukirjoja yms. Kyseisen materiaalin avulla voidaan tehdä ainakin alustavia päätelmiä siitä normi- ja 
arvoperustasta, johon tukeutumalla eri instituutiot, järjestöt ja musiikkiteollisuus ovat tuottaneet musiikin julkisen tarjonnan sisällön. Sitä kautta ne ovat päässeet määrittelemään musiikillisen kokemusmaailman luonnetta ja musiikillisten osakulttuurien rajoja.

\section{Lähteet}

Adorno, Theodor W.

1975 Einleitung in die Musiksoziologie. Zwölf theoretische Vorlesungen. Erste Taschenbuch Auflage. Suhrkamp Verlag.

Attali, Jacques

1985 Noise. The Political Economy of Music. Trans. by Brian Massumi. Manchester UP.

Autio, Juha-Pekka

1990 Dmitri Shostakovitshin rooli pietarilaisessa taiteilijaperinteessä 1922-1937. Kulttuurihistorian pro gradu -tutkielma (painamaton). Turun yliopisto.

Ballantine, Christopher

1984 Music and its social meanings. Gordon and Breach Science Publishers.

Ballstaedt, Andreas - Widmaier, Tobias

1989 Salonmusik. Zur Geschichte und Funktion einer bürgerlichen Musikpraxis. Franz Steiner Verlag.

Berggren, Olle (red.)

1977 Musik och samhälle. En antologi. Första upplagan. Bo Cavefors Bokförlag.

Blacking, John

1990 How musical is man? University of Washington Press (4. pa-

Bohman, Stefan

$$
\text { perback edition). }
$$

1985 Arbetarkultur och kultiverade arbetare. En studie av arbetarrörelsens musik. Nordiska Museet.

Bourdieu, Pierre

1986 Distinction. A Social Critique of the Judgement of Taste.

Transl. by Richard Nice. Routledge \& Kegan Paul Ltd 1.

Dahlhaus, Carl

1977 Grundlagen der Musikgeschichte. Musikverlag Hans Gerig. Dahlhaus, Carl

1980 Die Musik des 19. Jahrhunderts. Akademische Verlagsgesell- 
schaft Athenaion.

Dahlhaus, Carl

1983 "Is Music History a Form of Cultural History?" - Israel Studies in Musicology. Volume III. Israel Musicological Society s. $18-23$.

Dahlhaus, Carl

1988 Klassische und romantische Musikästhetik. Laaber-Verlag. Florén, Anders - Persson, Mats

1985 "Mentalitetshistoria och mentalitetsbegreppet." - Lychnos.

Lärdomshistoriska Samfundets Årsbok s. 189-203.

Fornäs, Johan

1982 "Musiikki porvarillisessa julkisuudessa." - Tiede \& Edistys no. 1 s. 4-14.

Frith, Simon

1987 "Towards an aesthetic of popular music." - Music and society. The politics of composition, performance and reception. Ed. by Richard Leppert and Susan McClary. Cambridge UP s. 133-149.

Frith, Simon - Goodwin, Andrew (Editors)

1990 On Record. Rock, pop and the written word. Pantheon Books.

Frykman, Jonas - Löfgren, Orvar

1989 Den kultiverade människan. Upplaga 1:9. Liber.

Gronow, Pekka

1966 "Suomalainen musiikkipolitiikka." - Suomen Musiikin

Vuosikirja 1965-1966. Toim. Veikko Helasvuo. Otava. s. 93102.

Gronow, Pekka

1975 "Kuka tuntee musiikin todellisuuden?" - Parnasso no. 1. s. 58-62.

Harnoncourt, Nikolaus

1986 Puhuva musiikki. Johdatusta musiikin uudenlaiseen ymmärtämiseen. Suomentanut Hannu Taanila. Otava.

Heiniö, Mikko

1986 "Taide- ja populaarimusiikki."- Etnomusikologian vuosikirja 1986. Toim. Vesa Kurkela ja Erkki Pekkilä. Suomen etnomusikologinen seura. s. 187-199.

Heister, Hanns-Werner

1983 Das Konzert. Theorie einer Kulturform. Band 1-2. Heinrichshofen's Verlag. 
Henttonen, Veli-Matti

1983 Jazz musiikkina ja kulttuuri-ilmiönä Suomessa ennen toista maailmansotaa. Tutkimus "mustan" musiikin ensimmäisistä vuosikymmenistä Suomessa. Yleisen historian pro gradu -tutkielma (painamaton). Turun yliopisto.

Jalkanen, Pekka

1989 Alaska, Bombay ja Billy Boy. Jazzkulttuurin murros Helsingissä 1920-luvulla. Suomen etnomusikologinen seura.

Kallioniemi, Kari

1990 Dandy, soul-mies ja rock-sankari. 60- luvun popmusiikki \& moderni kulttuuri. Kansan sivistystyön liitto.

Karbusicky, Vladimir

1975 Empirische Musiksoziologie. Erscheinungsformen, Theorie und Philosophie des Bezugs "Musik-Gesellschaft". Breitkopf \& Härtel.

Kurkela, Vesa

1989 Musiikkifolklorismi \& järjestökulttuuri. Kansanmusiikin ideologinen ja taiteellinen hyödyntäminen suomalaisissa musiikki- ja nuorisojärjestöissä. Suomen etnomusikologinen seura.

Kurkela, Vesa - Valkeila, Riitta (toim.)

1982 Musiikkikulttuurin murros teollistumisajan Suomessa. Raportti Suomen säveltaiteen juhlavuoden musiikintutkimuksen seminaarista Jyväskylässä 19.-21.5. 1982. Jyväskylän yliopiston musiikkitieteen laitos.

Laine, Anne

1987 Blues kulttuuri-ilmiönä. Kulttuurihistorian pro gradu -tutkielma (painamaton). Turun yliopisto.

Laitinen, Heikki

1990 "Rock taiteena, taidemusiikki elämänmuotona." - Tiede \& Edistys no. 1 (etnomusikologian teemanumero) s. 13-24.

Leisiö, Timo

1981 "Tyyli, tunne ja yhteiskunta. Näkökulmia suomalaiseen musiikkikulttuuriin." - Musiikki no. 3-4. s. 224-249.

Ling, Jan

1989 "Musik som klassisk konst. En 1700-talsidé som blev klassisk." - Frihetens former. En vänbok till Sven-Eric Liedman. Arkiv Förlag s. 171-187.

Lissa, Zofia

1983 "Zur Theorie der musikalischen Rezeption." - Rezeptions- 
forschung in der Musikwissenschaft. Hrsg. von Helmut

Rösing. Wissenschaftliche Buchgesellschaft s. 361-376.

Merriam, Alan

1964 The Anthropology of Music. Northwestern UP.

Mäki-Kulmala, Airi (toim.)

1982 Musiikki ja yhteisö. Musiikin, yhteisön ja musiikkiteollisuuden suhteista. Tampereen yliopisto, yhteiskuntatieteiden tutkimuslaitos. Sarja B. No. 34.

Nipperdey, Thomas

1988 Wie das Bürgertum die Moderne fand. Wolf Jobst Siedler Verlag.

Oramo, Ilkka

1974 "Musiikin todellisuus ja 'sosiologinen musiikinteoria'." Parnasso no. 6 s. 329-337.

Pattison, Robert

1987 The Triumph of Vulgarity. Rock Music in the Mirror of Romanticism. Oxford UP.

Prieberg, Fred K.

1982 Musik im NS-Staat. Fischer Taschenbuch Verlag. Raynor, Henry

1976 Music and Society Since 1815. Schocken Books. Russell, Dave

1987 Popular music in England, 1840-1914. A social history. Manchester UP.

Salmi, Hannu

1990 Mahdollinen Saksa. Säveltäjä Richard Wagnerin aatteellinen ja poliittinen toiminta kansallisen itseymmärryksen muokkaajana Saksan valtiollisen yhdentymisen vuosina 1864-1871. Yleisen historian lisensiaatintutkielma (painamaton). Turun yliopisto.

Sarjala, Jukka

1990 Kritiikki ja konserttimusiikki. Normit ja arvot helsinkiläisessä sinfoniakonserttimusiikin päivälehtikritiikissä vuosina 1918-1939. Kulttuurihistorian lisensiaatintutkielma (painamaton). Turun yliopisto.

Shepherd, John - Virden, Phil - Vulliamy, Graham - Wishart, Trevor

1977 Whose Music? A Sociology of Musical Languages. Latimer New Dimensions Ltd.

Sponheuer, Bernd

1987 Musik als Kunst und Nicht-Kunst. Untersuchungen zur 
Jukka Sarjala

Dichotomie von "hoher" und "niederer" Musik im musikästhetischen Denken zwischen Kant und Hanslick. BärenreiterVerlag.

Stockfelt, Ola

1988 Musik som lyssnandets konst. En analys av W.A. Mozarts symfoni no. 40, g-moll K. 550. Musikvetenskapliga institutionen i Göteborg.

Street, John

1986 Rebel Rock.

The Politics of Popular Music. Basil Blackwell Ltd.

Tarasti, Eero

1982 "Musiikintutkimuksen perusteita." - Taiteentutkimuksen perusteet. Toim. Yrjö Varpio. WSOY. s. 73-88.

Tarasti, Eero

1988 "Suomen musiikkitiede viime vuosikymmeninä - keitä olemme ja minne olemme menossa." - Etnomusikologian vuosikirja 1987-1988. Toim. Erkki Pekkilä \& Vesa Kurkela. Suomen etnomusikologinen seura s. 7-29.

Tawaststjerna, Erik

1965-1988

Jean Sibelius I-V. Otava.

Weber, William

1975 Music and the Middle Class. The Social Structure of Concert Life in London, Paris and Vienna. Croom Helm .

Westrup, Jack

1978 An Introduction to Musical History. 2nd edition, reprinted. Hutchinson Ltd.

Virtanen, Keijo

1984 "Kulttuurin käyttäjäkunnan laajeneminen: eliitti-/populaarikulttuuri 200 vuoden perspektiivinä." - Historiallinen Aikakauskirja no. 4 s. 269-276.

Wolff, Janet

1983 Aesthetics and the Sociology of Art. George Allen \& Unwin Ltd.

Wolff, Janet

"The ideology of autonomous art." - Music and society. The politics... (ks. edellä) s. 1-12. 